\title{
Institusioneel vasgeloop? Die Nederduitsch Hervormde Kerk van Afrika
}

\begin{tabular}{|c|c|}
\hline $\begin{array}{l}\text { Author: } \\
\text { Petrus L. Steer }\end{array}$ & kamp ${ }^{1}$ \\
\hline $\begin{array}{l}\text { Affiliation: } \\
{ }^{1} \text { Reformed The } \\
\text { College, Facult } \\
\text { University of P } \\
\text { South Africa }\end{array}$ & $\begin{array}{l}\text { eological } \\
\text { retoria, }\end{array}$ \\
\hline $\begin{array}{l}\text { Research Proje } \\
\text { Project Leade } \\
\text { Project Numb }\end{array}$ & $\begin{array}{l}\text { ect Registration: } \\
\text { r: A. Ungerer } \\
\text { er: } 82329542\end{array}$ \\
\hline $\begin{array}{l}\text { Description: } \\
\text { This research i } \\
\text { project, 'Conte } \\
\text { Reformed The } \\
\text { Africa', directe } \\
\text { Ungerer of the } \\
\text { Theological Co } \\
\text { of Theology, U } \\
\text { Pretoria. }\end{array}$ & $\begin{array}{l}\text { s part of the } \\
\text { extualized } \\
\text { ology in South } \\
\text { d by Dr Andre } \\
\text { Reformed } \\
\text { llege, Faculty } \\
\text { niversity of }\end{array}$ \\
\hline $\begin{array}{l}\text { Correspondin } \\
\text { Petrus Steenk } \\
\text { piet@4data.cc }\end{array}$ & $\begin{array}{l}\text { g author: } \\
\text { amp, } \\
. z a\end{array}$ \\
\hline $\begin{array}{l}\text { Dates: } \\
\text { Received: } 27 \mathrm{~J} \\
\text { Accepted: } 05 \\
\text { Published: } 17\end{array}$ & $\begin{array}{l}\text { une } 2017 \\
\text { Aug. } 2017 \\
\text { Nov. } 2017\end{array}$ \\
\hline $\begin{array}{l}\text { How to cite th } \\
\text { Steenkamp, P. } \\
\text { 'Institusioneel } \\
\text { Nederduitsch } \\
\text { Kerk van Afrik } \\
\text { Teologiese Stu } \\
\text { Theological St } \\
\text { a4719. https:/ } \\
\text { 10.4102/hts.v }\end{array}$ & $\begin{array}{l}\text { is article: } \\
\text { L., 2017, } \\
\text { vasgeloop? Die } \\
\text { Hervormde } \\
\text { a', HTS } \\
\text { dies/ } \\
\text { udies 73(1), } \\
\text { /doi.org/ } \\
\text { 73i1.4719 }\end{array}$ \\
\hline $\begin{array}{l}\text { Copyright: } \\
\text { (C) 2017. The A } \\
\text { Licensee: AOS } \\
\text { is licensed unc } \\
\text { Creative Comn } \\
\text { Attribution Lic }\end{array}$ & $\begin{array}{l}\text { uthors. } \\
\text { IS. This work } \\
\text { ler the } \\
\text { nons } \\
\text { ense. }\end{array}$ \\
\hline Read online: & \\
\hline 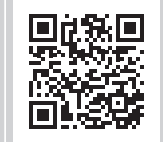 & $\begin{array}{l}\text { Scan this QR } \\
\text { code with your } \\
\text { smart phone or } \\
\text { mobile device } \\
\text { to read online. }\end{array}$ \\
\hline
\end{tabular}

The Netherdutch Reformed Church (Nederduitsch Hervormde Kerk van Afrika) finds itself in a precarious situation. It could be described as a watershed moment in the life of this denomination. The impasse developed due to various factors such as the loss of membership, the economic situation, ecumenical isolation and various other influences, which eventually resulted in a strong institutionalised organisation. Institutionalisation necessarily resulted in a shift of focus from the essence of being Church towards institutional continuation. As a result, the organic growth of the church suffered. This article investigates the institutionalism of the Netherdutch Reformed Church from an open (living) systems perspective, thereby identifying the dysfunctionality between form and function and ending with certain perspectives in respect of a change in focus by the church to realise the true essence of being Church of Jesus Christ.

\section{Inleiding}

Die navorsing wat hierdie artikel ten grondslag lê is vervat in twee besluite van die 70ste Algemene Kerkvergadering (AKV) van die NHKA (2013), nl. Besluit 74 en 75, beide vervat in die Agenda en Besluitebundel van die 70ste AKV.

\section{Funksie en vorm van kerkwees}

Die begrip model, word in verskeie kontekste gebruik. Die HAT (vyfde uitgawe, negende druk Odendaal en Gouws [reds]) beskryf die begrip soos volg:

Voorbeeld waarvolgens iets gemaak moet word = presiese replika; tipe gebruiksvoorwerp wat wissel volgens heersende smaak, nabootsing op 'n klein skaal, toonbeeld, volmaakte voorbeeld van iets.

Die Bestuurliteratuur gebruik die begrip in die sin van ' $n$ bloudruk, ' $n$ ontwerp wat toegepas word, 'n grafiese of wiskundige (simboliese), fisiese of verbale voorstelling van 'n konsep of 'n vereenvoudigde weergawe van 'n fenomeen of 'n verhouding tussen verskillende dimensies (Wheatley 1992).

'n Model abstraheer in alle gevalle sekere elemente van 'n saak of voorwerp/objek. Drie tipes modelle kan onderskei word: Ikoniese modelle is die minste abstrak en verteenwoordig ' $n$ werklike weergawe van die werklikheid. Analogiese modelle is meer abstrak maar het verwysende kwaliteite van die objek waarna verwys word. Simboliese modelle is die mees abstrakte met uiters min of geen verwysende karakter van wat daardeur verteenwoordig word nie.

Indien die bedoeling onderliggend aan die voorstelle geleë is in die soeke na 'n alternatiewe befondsingaanslag, sou 'Kerkmodel' waarskynlik verwys na die wyse waarop die besluite van die AKV befonds sou kon word. Dit impliseer dat die huidige heffingstelsel hersien moet word in samehang met 'n meer effektiewe bestuur en benutting van bestaande infrastruktuur en bronne.

Indien die begrip 'kerkmodel' na gemeentelike bediening en organisatoriese praktyk verwys, is dit ' $n$ ander fokus as bekostigbaarheid en is dit ingebed in die verantwoordelikheidsdomein van die plaaslike kerkraad wat na gelang van die plaaslike omstandighede gereël, georden en in werking gestel word.

Die HAT beskryf die begrip vorm in verskeie kontekste waarvan twee waarskynlik die naaste aan die huidige denkproses lê: Uiterlik, gedaante, fatsoen, vaste patroon gewoonte, formaliteit, konvensie.

Die Bestuurliteratuur beskryf die begrip vorm as die gestalte of die visuele voorkoms, of die manier waarop dinge gedoen word en beantwoord die vraag hoe? Dit sou ook moontlik wees om 
die begrip Gestalt hier te gebruik in die sin dat vorm verwys na die geheel. Ander moontlikhede sluit in die essensie van iets, die wyse waarop ' $n$ ding bestaan, prosedure, ' $n$ vaste patroon, die bewese vermoë om take uit te voer.

In die samehang tussen die twee begrippe (funksie en vorm) lê daar 'n kronologiese verloop. Vorm volg op funksie soos wat die struktuur van 'n organisasie volg op strategie. Dit sou 'n 'kortsluiting' veroorsaak indien 'n vorm (model) geskep word sonder om die transformasie binne die NHKA in aanmerking te neem. Laasgenoemde moet in die kronologiese verloop van funksie en vorm eers verdiskonteer word.

Die onderliggende toon van die 70ste AKV sou getipeer kon word as 'n ernstige en dringende soeke na antwoorde in die lig van:

Die huidige ekonomiese en maatskaplike omstandighede; kleinerwordende lidmaatgetalle; die besef dat die NHKA vir dekades aan 'n instituut gebou het en iets van organiese groei verloor het; ie NHKA as Kerk van Christus het vir te lank ingebed geraak het in die kulturele leefwêreld van 'n spesifieke groepering in die Suid-Afrikaanse samelewing; Die afskeiding van aantal gemeentes en die gevolglike verlies van lidmate.

Die narratief wat gebruik word in die soeke na 'n alternatiewe model van kerkwees word gekodeer as die bekostigbaarheid van kerkwees op gemeentevlak.

Die effek van die ekonomiese situasie in die land op die bekostigbaarheid van kerkwees moet nie onderskat word nie. Wat ook in hierdie narratief raak gelees moet word is die beskerming van en die volhoubaarheid van standplase as werkgeleentheid vir predikante, wat uiteraard 'n spanning tussen roeping en beroep meebring.

Hoe hierdie narratief ook al verstaan word; die wyse waarop die NHKA haarself as kerk in die wêreld georden het is nie volhoubaar nie. Alhoewel hierdie faktore wel aanleiding gegee het tot verkleining, is daar ook ander faktore wat nie so maklik gekwantifiseer is nie, wat ook 'n bydrae gelewer het tot die verkleining van die NHKA.

\section{Wat word verstaan onder die begrip 'institusionalisering'?}

Jesus het geen intensie gehad om 'n kerk te stig nie. Hy het ook geen kerklike model of kerklike strukture nagelaat met die bedoeling dat dit vir die kerk gebruik moes word wat later gevolg het nie. Hy het die koninkryk van God verkondig, en iets van die koninkryk van God sigbaar gemaak hier op aarde, deur die manier waarop Hy geleef het. (Jones \& Van Eck 2010:6)

Dreyer (2002) beskryf die proses van institusionalisering soos laasgenoemde geoperasionaliseer word met die oog op die ontwikkeling van kerklike leierskap. Die strukturering van sosiale groepe waarby die kerk ingesluit word, is ' $n$ deurlopende proses, waartydens mense as die agente wat sosiale groepe struktureer aan die hand van bestaande praktyke wat dan gelegitimeer word op grond van die praktyke. In die geval van die NHKA is dieselfde proses voltrek, gebaseer op 'ideologiese' perspektiewe. Die strukturering en gevolglike institusionalisering van 'n sosiale groep of 'n gemeenskap soos die Kerk kan nie plaasvind sonder menslike ingrepe nie.

Human society would plainly not exist without human agency. But it is not the case that actors create social systems. They reproduce or transform them, remaking what is already made in the continuity of praxis. (Dreyer 2002:626)

Wanneer en hoe ontstaan institusionalisering in sosiale gemeenskappe? Dreyer (2002) formuleer dit soos volg:

Human beings are creatures of habit, in other words, their behaviour follows certain repetitive patterns. Habit provides the impetus for institutionalisation. Another human trait is typification, the mental activity of classifying according to typical acts or characteristics. When the typification is done collectively rather than individually, it can be referred to as roles. An institution is represented in and by roles. Role expectations are formed when people come to expect typical behaviours. (p. 631)

In hierdie opsig kan gedink word aan die rol van vergaderings en ampsdraers binne die kerklike struktuur. Praktyke en daarmee saam, rolle, word geyk. Die geyktheid van rolle wat deur praxis ontwikkel, skep dan verwagtings wat vasgelê word in gedokumenteerde riglyne soos 'n Kerkorde. Hierdie verwagtings word deur oorlewering en geykte praktyke vasgelê in die denke en verwagtings van lidmate en ampsdraers wat enige afwyking as 'n verbreking van die reëls beskou. Sodoende word sosiale beheer uitgeoefen en word afwykings beskou as 'n kontraindikasie van orde.

This means that it has no formal control, but its power lies in how difficult it is for individuals to go against the system. On the one hand this social control has the effect of limiting an individual's freedom. But on the other, institutionalisation also has the effect of creating a structured world for individuals. (Dreyer 2002:631)

Uit die aanvanklike institusionaliseringsproses ontwikkel 'n kumulatiewe institusionaliseringstendens wat die kompleksiteit van die instelling verhoog en transformasie bemoeilik.

Meer spesifiek op die kerklike terrein verwys Dreyer (2002:636-637) daarna dat die name van Jesus in die na-pase periode verhef is tot titels omdat die na-pase gemeenskap mag aan Jesus toegeken het. Wanneer 'n naam omvorm word tot 'n titel, word dit 'resources of a symbolic and linguistic nature'. Hierdie 'simboliese bronne' funksioneer dan op 'n ideologiese vlak om dominansie te legitimeer. Die ontwikkeling vanaf charismatiese gesag (die historiese Jesus) tot geïnstitusionaliseerde mag (die vroeë kerk) kan dan gesien word as 'n selektiewe aanpassing wat belyn word met sekulêre magstrukture:

This could seem to be an innocent natural process if one is not aware of the dangers it holds. In a postmodern hermeneutical process demystification exposes these 'natural' and 'legitimate' 
values as concealing underlying ideological motives. (Dreyer 2002:637)

Struktuur skep die lewensruimte vir 'n instelling om sy visie en doel na te streef (vir die kerk: haar roeping). Dit moet egter sodanig ingerig word dat dit nie die funksionering van die instelling strem nie maar juis die lewensruimte daarstel waarbinne die visie en doel ten beste bevorder kan word. Visie gaan struktuur vooraf. Indien die omgekeerde proses gevolg word, word die fokus verskuif na die instandhouding van die struktuur en die instituut. Die sirkelgang van institusionalisering; de-institusionalisering; herinstitusionalisering volg ' $n$ onvermydelike proses van transformasie ten einde die primêre funksie van die instelling weer op die voorgrond te plaas. Hierdie uitgangspunt geld veral vir die Kerk. Jones en Van Eck (2010) werk met die begrip roeping en wys daarop dat die Kerk geroep is tot dissipelskap:

In die kerk behoort strukture nie ten koste van die verkondiging van, en positiewe antwoord op, Jesus se oproep tot dissipelskap in stand gehou te word nie. Die positiewe antwoord op Jesus se oproep tot dissipelskap moet (in elke nuwe konteks) tot 'n bepaalde struktuur lei. Wanneer charisma geïnstitusionaliseer word om aan ampswerk uitvoering te gee, is dit nie die struktuur wat as maatstaf van institusionalisering moet dien nie, maar eerder dit wat die Skrif leer. Jesus se oproep tot dissipelskap, en diensbaarheid as deel van dissipelskap, behoort te bepaal hoe die struktuur moet lyk. (p. 8)

Institusionalisering vind plaas in 'n definieerbare en spesifiek identifiseerbare konteks en kan beskryf word as die vestiging van gedragsvorming 'wat gegrond is in charisma, (en) dien as die impuls wat daartoe lei dat 'n bepaalde groep hom van die res van die samelewing afgrens' (Jones \& Van Eck 2010:8). Hierdeur word 'n bepaalde identiteit gevorm wat die organisasie/entiteit se doeltreffendheid en effektiwiteit dien. Dit spreek vanself dat wanneer:

die eise van die omstandighede verander, of wanneer die groep sy doel bereik het, die kans goed is dat 'n nuwe visie en doel geformuleer word ten einde by die nuwe omstandighede of nuwe eise aan te pas. (Jones \& Van Eck 2010:7)

Die proses van institusionalisering, de-institusionalisering en herinstitusionalisering vind dus deurlopend in sosiale groepe plaas.

Veranderende omstandighede en 'n evolusionêre konteks gee aanleiding tot 'n heraanpassing van praxis en denkstrukture wat lei tot groter effektiwiteit en volhoubare voortbestaan van die groep. Dit is 'n deurlopende proses waartydens strukture verander en aangepas word. Hierdie deurlopende proses lei onvermydelik weer tot 'n institusionaliseringsproses wat aan die eise van die tydsgewrig moet voldoen ten einde doelmatig te bly funksioneer. Gebruike en praktyke van die verlede het nie ewigheidswaarde nie.

Dit is juis besluite en denkpatrone wat uit die sistemiese omgewing waarin die NHKA haarself bevind het, wat aanleiding gegee het tot die huidige strukture en die gevolglike krisis wat met die narratief 'onbekostigbaarheid' aangedui word.

\section{Metode van ondersoek}

Beskrywingspunt 74 bepaal dat die ondersoek aan die hand van Organisasie analise, ontwerp en Ontwikkelingsteorie gedoen sal word.

Organisasie analise is die proses aan die hand waarvan 'n organisasie in sy geheel ondersoek word en word dikwels geïnisieer wanneer daar 'n krisis ontwikkel of wanneer bepaalde omstandighede die analise noodsaak met die oog op beplande verandering. Periodieke analise lewer ' $n$ bydrae tot die evaluering van effektiwiteit en moontlike aanpassings in prosesse of prosedures. Die einddoel is die versterking van effektiwiteit en doelgerigtheid van die organisasie se oorlewingsmoontlikhede.

Tydens die proses word die dinamika binne die organisasie blootgelê. Daarom is die gebruik van teoretiese modelle belangrik. Hiersonder word dit moeilik om die interaksie en dinamiese prosesse van informasievloei, asook die funksionele of disfunksionele prosesse te identifiseer, gevolgtrekkings te maak en moontlike regstellings te maak.

Daar moes uiteraard 'n keuse uitgeoefen word vir 'n spesifieke teoretiese model nadat verskeie modelle oorweeg is. Die keuse het geval op Lewende Sisteemteorie as teoretiese model.

\section{Keuse van 'Living Systems Theory' (Lewende Sisteemteorie: LST)}

Dit is onwenslik om die navorsing oor bepaalde sake in isolasie te doen. Deur slegs na 'n probleem aard in isolasie te kyk en daarvoor oplossings te soek, doen nie reg aan die sistemiese prosesse van kerkwees nie. Volhoubaarheid van kerkwees: (Verslag 2015:17).

'n Wysiging aan een aspek of faset van kerkwees in terme van die soeke na 'n alternatiewe model, sal noodwendig in die res van die sisteem 'n bepaalde gevolg hê wat 'n verdraaide perspektief tot gevolg sal hê. Om hierdie rede is besluit op 'n sistemiese of holistiese, verstaansraamwerk vir die ondersoek. Die teoretiese raamwerk wat hiervoor gekies is, is die Teorie van Lewende Sisteme (LST). As 'n algemene sisteemteoretiese raamwerk bied dit 'n verstaansraamwerk aan die hand waarvan lewende en sosiale sisteme en die onderlinge dinamika ontleed en verstaan kan word. Dit bied 'n omvattende en holistiese perspektief op die totale sisteem en die samehangende verband tussen subsisteme binne die geheel.

\section{Agtergrond tot die teorie van lewende sisteme}

Lewende Sisteemteorie is 'n algemene sisteemteorie wat betrekking het op die funksionering van 'lewende sisteme' 
en hou verband met die ontstaan, funksionering, selfinstandhouding en voortbestaan (Miller 1978). As 'n holistiese raamwerk, is LST ideaal om verweefde en uiteenlopende prosesse en strukture te verstaan. Daarom is LST geoperasionaliseer om die kerk as ' $n$ unieke organisatoriese verskyningsvorm in samelewingsverband te begryp. Dit is belangrik om onderskeid te tref tussen LST en tradisionele sisteemdenke wat spruit uit 'n modernistiese denkraamwerk (sien Tabel 1).

When the Christendom mode of church fails to respond to outside stimuli by disengaging from the organic experience and becomes purely self-referential, then you can be sure it is on its way out. (Brisco 2014, aangehaal in die Verslag 2015)

'Living systems are open self-organizing living things that interact with their environment' (Wheatley 1992:78) en word in stand gehou deur die vloei van informasie, energie en materie. So 'n benadering verteenwoordig die teendeel van die tendens om die geheel in onderdele en komponente te verdeel. Brown (2002) stel dat 'general living systems theory explores phenomena in terms of dynamic patterns of the relationships of organisms with their environment'. Dit verskuif die fokus vanaf statiese stabiliteit na prosesse waardeur oop sisteme groei en aanpas (Steenkamp 1997; sien ook Ackoff 1981; Flood \& Carson 1993; Lorentsson 2001). In elk van die sewe sisteem-hiërargieë is dieselfde subsisteme werksaam (Miller 1978; sien ook Van Zyl \& Delport 1993:2). In LST word oorspronklik 19 subsisteme gekonstrueer wat van mekaar onderskei word in terme van kompleksiteit van funksionering.

Een konsekwensie van die onderlinge verhouding van sisteemkomponente en die dinamiese interaksie binne die geheel, is die fenomeen van verskyning of sigbaarwording (emergence). In 'n lewende sisteem verskyn bepaalde fenomene wanneer die geheel groter is as die somtotaal van die dele.

\section{'n Sistemiese perspektief binne die teoretiese raamwerk van lewende sisteme}

Om die impasse waarin die NHKA haarself bevind te verstaan, is dit nodig om kerk te sien as, onder andere, 'n

TABEL 1: Vergelyking: Tradisionele sisteem eienskappe versus oopsisteem eienskappe.

\begin{tabular}{|c|c|}
\hline Tradisionele Sisteemeienskappe & Lewende /Oop Sisteem eienskappe \\
\hline $\begin{array}{l}\text { Geslotenheid } \\
\text { Neig tot ekwilibrium en afsterwe }\end{array}$ & $\begin{array}{l}\text { Openheid } \\
\text { Neig tot openheid en selvernuwing of } \\
\text { 'ontwrigting en kontinue aanpassing en } \\
\text { transformasie' (in die geval van kerkwees dalk } \\
\text { eerder Reformasie) as gevolg van die inname, } \\
\text { insette en invloede vanuit sowel eksterne } \\
\text { omgewing as die interne sistemiese omgewing }\end{array}$ \\
\hline Staties en manipuleerbaar & Selforganiserend en dinamies van aard \\
\hline \multirow[t]{2}{*}{$\begin{array}{l}\text { Fragmentaries in benadering. } \\
\text { Verdeel die geheel in losstaande } \\
\text { en afsonderlike eenhede }\end{array}$} & $\begin{array}{l}\text { Ondersoek en beskryf die geheel. 'Living systems } \\
\text { are open self-organizing living things that interact } \\
\text { with their environment' (Wheatley 1992:78) }\end{array}$ \\
\hline & $\begin{array}{l}\text { Oop sisteme bestaan dus uit die samehangende } \\
\text { dinamika van die onderling wederkerige } \\
\text { interaksie van alle subsisteme (Flood \& Carson } \\
\text { 1993; Sien ook Steenkamp 1997) }\end{array}$ \\
\hline
\end{tabular}

a, Margaret Wheatley (1992) bevestig dit deur te verwys na die neiging van oop sisteme om in ' $n$ voortdurende staat van non-ekwilibrium te wees, aangesien sulke sisteme deelneem in 'n aktiewe interaksie en 'uitruilproses' met die wêreld waarin hulle funksioneer ter wille van voortbestaan. sigbare gemeenskap in die wêreld van instellings. Die kerk se wese onderskei haar van ander organisatoriese instellings. Daar is weinig organisasies waarmee die kerk vergelyk kan word en tog kan die organisatoriese dimensie van die kerk as instituut, nie ontken word nie.

Vir die doeleindes van hierdie artikel moet die grense nouer getrek word en moet gemeentes binne die ruimte van die NHKA geplaas word. As verskyningsvorm in elke samelewingsverband, bied die kerk haar aan as 'n sigbare entiteit waarbinne sekere organisatoriese dimensies waarneembaar is en wat deur beplanning en ander bestuurbeginsels georden word. Die kerk se roeping is om die Evangelieboodskap, binne samelewingsverband, te verkondig (Mtt 28:19).

Die kerk word sigbaar as 'n organisatoriese entiteit wat lokaal (gemeente) en nasionaal (NHKA) lokaliseerbaar is. ${ }^{2}$ Wat noodwendig hierop volg is om die Kerk in eie reg te sien as 'n instituut met organisatoriese dimensies.

Dit is belangrik om die verhouding tussen die missio Dei en die kerk as gedefinieerde subjek te konstateer. Wanneer die missio Dei die vertrekpunt is - gebeur die kerk van Christus in die wêreld, en sal die organiese groei van die Kerk vanself na vore tree (emerge). Wanneer die instituut op die voorgrond geplaas word, sal ons noodwendig 'n meganistiese en masjienagtige benadering volg en sal die intrinsieke spirituele/ geloofsperspektief as die motivering vir die missio Dei noodwendig op die agtergrond tree. Die missio Dei moet die organiserende beginsel wees - en in die geval van die NHKA word.

\section{Die NHKA as sistemiese entiteit}

Die identifiseerbare entiteite of subsisteme moet binne die ruimte van die kerk geposisioneer wees. Die onderlinge samehang van die onderskeie subsisteme moet ingesien word aangesien dit van wesenlike belang is vir die kerk se funksionering op 'n sigbaar-organisatoriese vlak. Hiermee word die geloofwerklikheid nie ontken nie. Hierbo is verwys na die onderlinge oorvleueling van die missio Dei en die geïnstitusionaliseerde verskyningsvorm van die kerk. Wanneer bevind word dat een of meer van die kritiese subsisteme nie gesinchroniseer is met ander nie of nie ten volle operasioneel funksioneer nie, dui dit op sistemiese disfunksie. Die interne kommunikasieproses en vloei van inligting blyk die wesenlike dimensie te wees wat die integriteit van die sisteem in stand hou en wat tegelykertyd die dinamiese energie daarstel wat die sisteem in voortdurende verandering of beweging hou. Die voorwaardevirhierdie dinamiekisdatdieorganisasiesisteem oop moet wees om inligting vanuit die omgewing te ontvang en inligtingvloei in die interne omgewing in beweging te hou.

1.Nuwe Afrikaanse Vertaling 1983.

2.Malan Nel (2015) tref 'n onderskeid tussen die gedefinieerde subjek en die empiriese subjek. 


\section{Die besluitnemingproses}

Wanneer die AKV in sitting is, neem die vergadering besluite wat uitvoering verg. Na afloop van die AKV vorm die gekose Kommissie van die AKV 'n voortsettingsliggaam met die opdrag om toe te sien dat die besluite van die AKV tussen sittings uitgevoer word. Die Kommissie van die AKV (Kommissie) stel benewens die rade wat deur die AKV aangewys word, liggame aan met die opdrag om sekere opdragte soos in die goedgekeurde beskrywingspunte vervat, uit te voer. Besluite word in die notule en besluitebundel van die AKV opgeneem en word aan predikante en kerkrade gekommunikeer met die verstandhouding dat die inligting in gemeentes gedissemineer word. Die begroting word bekend gemaak en die sinodale kantoor se dienslewering neem 'n aanvang.

Ten spyte van pogings om die besluite af te wentel tot op gemeentevlak, blyk dit nie noodwendig die geval te wees nie. Wanneer informeel ${ }^{3}$ navraag gedoen word na afwenteling, blyk dit dat dit selektief plaasvind. Die kommunikasie van besluite blyk dus nie so eenvoudig te wees as wat dit op die oog af voorkom nie. Die onwillekeurige vraag is of die huidige kommunikasieprosesse en inligting disseminasie effektief is? Hiermee saam moet ook gevra word waar die blokkasies is? Asook: Weet lidmate hoe die besluitnemingsprosesse verloop? Dit gaan per slot van rekening oor die kollektiewe verband van die gemeentes van die kerk wat assosiatief met mekaar in verband staan op grond van die belydenis. Aangesien die AKV slegs elke drie jaar in sitting is, is die siklus van besluitneming en uitvoering redelik omslagtig en tydrowend. Ten einde hierdie probleem te oorkom het die Kommissie van die AKV 'n nuwe Bestuurmodel geïmplementeer met die oog op kontrole van die uitvoering van gedelegeerde opdragte.

Die sinodale diensleweringsisteem bepaal heffings nie selfstandig of onafhanklik nie. Die Raad van Finansies neem kennis van die aktiwiteite en stel dan ' $n$ begroting saam wat sodanige aktiwiteite kan diens. Aktiwiteite wat onderhou word, se bekostiging word afgewentel na gemeentes in die vorm van sinodale offergawes. Die sleutel bestuursbegrip hier is, ekonomieë van skaal. Dit is makliker en meer bekostigbaar om kollektief te beding vir die beste voordele wanneer die bedinging op die basis van die kollektiewe eenheid van die Kerk plaasvind.

\section{Afleidings}

\section{Afleiding 1}

Geslotenheid teenoor openheid: Die NHKA het 'n geslotenheid gehandhaaf wat in teenstelling tot openheid, gelei het tot marginalisering.

3.Verskeie kollegas het tydens informele gesprekke laat blyk dat selfs predikante nie bewus is of kennis dra van die prosesse en besluite van die AKV nie, en dat talle nie bewus is of kennis dra van die aktiwiteite wat deur die sinodale kantoor uitgevoe word nie.

\section{Afleiding 2}

Instituut teenoor organisme: Die NHKA het 'n sterk institusionele fokus geskep en gehandhaaf.

\section{Afleiding 3}

Marginalisering teenoor aanvaarding: In die strewe tot 'n eiesoortige bestaanswyse, dikwels deur selfopgelegde isolasie en as gevolg van sekondêre oorwegings, het die NHKA 'n negatiewe beeld in die samelewing gekry as gevolg waarvan die kerk gemarginaliseer geraak het.

\section{Afleiding 4}

Tred hou met verandering teenoor gestoldheid: Die NHKA blyk nie tred te gehou het met die verskuiwende paradigma in die samelewing met betrekking tot godsdienstige perspektiewe nie. Hiermee moet die oënskynlike onvermoë om lidmate in veranderende tye te begelei, saamgelees word.

\section{'n Narratiewe analise van die NHKA as 'n identifiseerbare (definieer- bare) sisteem in eie reg}

\section{Afleiding 1}

Lukraak teenoor gekoördineerde besluitneming en kommunikasie:

- Ongekoördineerde besluite asook kommunikasie van die besluite.

- Baie besluitnemers wat kommunikeer skep verwarring ten opsigte van die onderlinge verband met mekaar.

- Die konteks van waaruit verskillende rolspelers boodskappe kodeer en versend, is uiteenlopend van aard.

- Kommunikasie/Inligting word soms gelyktydig deur verskillende rolspelers versend.

- Die inhoud van inligting asook die struktuur daarvan, gegewe die kontekstuele koderingsproses, lei tot verwarrende boodskappe.

- Gemeentes weet nie altyd wat om met al die inligting te doen nie.

- Die kommunikasielyne binne die kerklike opset is gekruis. Soms word botsende boodskappe oorgedra wat verwarrend inwerk en soms ook direk weersprekend geïnterpreteer kan word, wat meermale tot dissonansie kan lei.

\section{Afleiding 2}

Bewus teenoor onbewus van sinodale aktiwiteite: Lidmate en selfs kerkrade is nie bewus van die aktiwiteite wat uitgevoer word deur die sinodale diensleweringsisteem, namens vergaderings van ampte en die besluite wat geneem word, nie.

\section{Afleiding 3}

Besluite van vergaderings en die finansiële impak: Vergaderings neem besluite wat 'n direkte invloed het op die 
finansiële bydraes van lidmate en gemeentes. Die AKV se besluite raak die hele Kerk en indirek elke afsonderlike lidmaat se bydrae. Hierbenewens is daar ook 'n aanspraak deur ringsvergaderings, die ADV en daarmee saam die organe van bystand, die ringsdiakonale rade en versoeke deur Bejaardesorg, Kindersorg en die NHSV. Hierdie aansprake/versoeke berus op 'n emosionele appèl wat beswaarlik geweier kan word.

\section{Afleiding 4}

Parallelle/onafhanklike funksionering: Daar bestaan 'n persepsie dat die ADV en organe van bystand onafhanklik langs die kollektiewe verband van die NHKA funksioneer.

\section{Afleiding 5}

Diskontinuïteit in ampsfunksionering teenoor gesinkroniseerde kontinuïteit: Die totstandkoming van die ADV het tot gevolg dat daar'n mate van diskontinuïteit in die funksionering van die ampte binne gemeentelike verband en die NHKA as 'n sistemiese geheel ontstaan het. Alle bedieningsaktiwiteite hoort tuis binne gemeentelike verband waar 'n sistemiese kontinuïteit tussen leitourgia en die daaruit voortvloeiende missionale bediening deur ampsdraers en lidmate moet bestaan. Hierdie perspektief is nie net funksioneel geldig nie, maar ook teologies en ekklesiologies suiwer.

\section{Afleiding 6}

Tegnologie vervang die erediensbyeenkoms: Die tegnologiese ontwikkeling en die gebruik van veral TV om godsdiensprogramme en eredienste te beeldsend, erodeer erediensbywoning.

\section{Afleiding 7}

Sinodale institusie en poste: Mede as gevolg van 'n sterk institusionele fokus, het die NHKA 'n effektiewe dog uitgebreide sinodale struktuur. Hierdie ontwikkeling het as 'n historiese proses, uit 'n ekspansionistiese era, gegroei. Sake bedrywighede, wat ' $n$ baie belangrike rol gespeel het in die finansiering van kerklike aktiwiteite het daartoe bygedra dat 'n sterk sinodale administrasie ontwikkel het. Die Administrateur van die Kerk het 'n belangrike rol vervul as die Hoof Uitvoerende Beampte van die Kerk. As gevolg van die inkrimping van die ekonomie sedert die tagtigerjare van die vorige eeu, het die sake- bedrywe van die Kerk ook gekrimp. Poste wat mettertyd geskep is, het 'n oorhoofse postestruktuur beslag gekry naamlik: die uitvoerende pos van die Administrateur, Hoof Rekenmeester, die oudit afdeling, Sekretaris van die Kommissie, Kital, wat later omskep is tot SENTIK, 'n Sendingkantoor met 'n voltydse Superintendent, die opleiding van predikante van die nou MRCC wat uitgebrei het tot 'n eie opleiding met voltydse dosente en nog vele meer. Die afskalingsproses het gelei tot die sluiting van die opleidingsfasiliteit te Klipdrift. In die plek daarvan is AIM geskep. Wat kommunikasie en tydskrifte betref is SENTIK in die plek van KITAL geskep met die opdrag kommunikasie en tydskrifte. Die Administrateursrol het afgeskaal vanaf 'n Hoof uitvoerende Beampte tot dié van 'n koördinerende beampte. Die pos van Sekretaris het behoue gebly, maar het 'n transformasie ondergaan. ${ }^{4}$

\section{Die gemeente as verskyningsvorm in die sinodaal-sistemiese verband Afleiding 1}

Die oorlading van predikantsamp: Hierdie afleiding blyk 'n direkte gevolg te wees van die ondermyning/verval van die amp van die gelowige. Lidmate abdikeer hulle verantwoordelikheid ten opsigte van kerkwees en verplaas die verantwoordelikheid na veral predikante. Hierdie uitspraak moet gesien word teen die agtergrond dat lidmate ontvangers van woordbediening word en nie meer self eienaarskap aanvaar vir gemeentelike bedieningfunksies nie. Waar lidmate wel betrokke is, is dit ter wille van oorlewing en inkomste, dus instandhouding teenoor groei in geloof. Die dienswerk van die gelowige het hiermee in die slag gebly.

\section{Afleiding 2}

Fokus op instandhoudingfunksies en oorlewing: Soos blyk uit ' $n$ oorsigtelike nagaan van gemeentelike begrotings en uitgawes, is die oorwegende klem op die instandhouding.

\section{Afleiding 3}

Die lewensiklus van gemeentes 'n noodwendigheid: Gemeentes deurleef 'n siklus vanaf stigting deur die verskillende lewensfases totdat ' $n$ afwaartse kurwe intree. Gemeentes hou in die meerderheid gevalle nie rekening hiermee nie. Gemeentes wat aanvanklik dinamies en lewenskragtig was, verloor momentum as gevolg van 'n verskeidenheid van faktore.

\section{Afleiding 4}

Weerstand teen verandering: 'n Gestoldheid in gemeentelike praktyk en prosesse lei tot die handhawing van tradisie en gemeentelike kultuur as die enigste geldende norm vir gemeente wees (institusionalisering). Wanneer 'n poging tot vernuwing geloods word, sal vanuit 'n gestolde paradigma noodwendig sterk weerstand teen verandering ervaar word.

\section{Afleiding 5}

Verwaarlosing van die groeipotensiaal in die gemeente en gemeenskap: Daar bestaan waarskynlik in elke gemeenskap en gemeente (op enkele uitsonderings na) potensiaal vir groei. $^{5}$

4. Hierin word nie ' $n$ volledige lys van poste bespreek nie. As gevolg van ' rasionalisering en afskalingsproses is verskeie poste herposisioneer.

5.Groei in hierdie verband moet nie noodwendig gesien word as slegs getallegroei nie, maar as ' $n$ verdieping in geloof (spiritualiteit) en ' $n$ missionale uitreik na die gemeenskap. 


\section{Afleiding 6}

Geykte gemeentelike organisasie en bestuur: Daar bestaan, in aansluiting by afleiding 6, ander binne-gemeentelike inrigtingsmoontlikhede wat 'n dinamieser gemeentelike lewe tot gevolg kan hê. Ons is vasgevang in 'n burokratiese organisasie paradigma.

\section{Afleiding 7}

Gestolde begrotingfokus: Die huidige begrotingpatroon plaas 'n swaar klem op 'n tradisionele finansiële bestuur in gemeentes. Dit weerspieël 'n sterk institusioneel georiënteerde benadering. Dit kan sinvoller bedieningfokus tot gevolg hê indien gemeentes eerder na'n aktiwiteitgedrewe begroting beweeg.

\section{Afleiding 8}

Risiko's: Gegewe die waarneming dat 'n groot getal gemeentes se finansiële inligting ontbreek, word die risiko om alle sinodale verpligtinge soos deur die AKV bepaal, groter. Dit plaas nie alleen gemeentes op risiko wat wetgewing betref nie, maar ondermyn ook sinvolle dienslewering op sinodale vlak. Hierdie neiging kan beskryf word as 'n neiging tot ' $n$ independentistiese bestaanswyse.

\section{Afleiding 9}

Lidmate as individue in lewensrolle: Lidmate moet voldoen aan die menslike toestand en aan al die verwagtings wat uit die perspektief van 'n groot verskeidenheid lewensrolle gestel word. Hierteenoor behoort die Kerk en gemeente (spesifiek) 'n geestelike/spirituele ruimte daar te stel wat kan lei tot sinbelewing.

\section{Afleiding 10}

Die afwenteling van geïsoleerde besluite en die huidige tydgees: Die Kerk bevind haar in 'n radikaal andersoortige tydgees as tien of 15 jaar gelede. Lidmate soek sin in gesamentlike besluitneming en gedeelde waardes wat nie alleen geloofwaardes insluit nie, maar ook algemene lewenswaardes. By gebrek aan betrokkenheid en deelnemende besluitneming, verloor mense belangstelling en onttrek.

\section{Afleiding 11}

Uitgediende leierskapstyl: Leierskapstyl in die Kerk word dikwels beleef as outoritêr, direktief en geslote. Die Kerk kan nie meer bekostig om 'n leierskapstyl te handhaaf wat uit die modernisme stam nie.

\section{Hoe het ons gekom waar ons is en hoe lyk ons nou?}

Die primêre probleemveld waarmee die NHKA tans worstel is geleë in die institusionele en organisatoriese verwording ten koste van die Missio $\mathrm{Dei}^{6}$ en die apostolaat-opdrag (Mtt 28:19, Luk 10 en ander soortgelyke perspektiewe). Die institusionele fokus het wye uitlopers wat alle dimensies van kerkwees raak en beïnvloed.

Die kompleksiteit van die probleemaard kan nie ontken word nie. Daar is nog talle dimensies wat nie hierin aangeraak is nie wat 'n verdere invloed uitoefen, en uitgeoefen het, op die na-binne gerigtheid van die NHKA.

Hoe dit ook al sy, die NHKA word tans gekonfronteer met 'n probleemkompleks. So 'n probleemaard kan nie opgelos word deur 'n enkele of reglynige oplossing nie. Dieselfde kompleksiteit wat tot die huidige stand binne die NHKA aanleiding gegee het, kan slegs deur 'n soortgelyke kompleks van potensiële oplossings aangespreek word.

Bostaande het voldoende aangetoon dat die NHKA in 'n institusionele groef verval het (sien ook Dreyer 2016).

\section{'n Nuwe koers}

Daar is reeds in 1995 gepleit het vir 'n nuwe benadering tot kerkwees.

Die wisseling van die eeu (.. en die millennium) ... konfronteer (ons) met die mislukking van so byna alles waarmee die kerk hom besig gehou het. Die groei van die kerk het negatief geword, ekonomies worstel hy om te bestaan, sy teologiese voorraad is in baie opsigte onbruikbaar, sy politieke erfenis in skerwe ... (Dreyer 2011:2)

Die kerk, op voetspoor van Rasionalisme van die 18de eeu (Rousseau: I'Contrat Social), (volgens Spoelstra), (en) Kuyper se filosofie van soewereiniteit in eie kring en die Filosofiese Wetsidee, het die kerkbegrip onder neo-Calviniste in Nederland gesekulariseer en verhorisontaliseer sodat die kerk gedefinieer word as een van 'n veelvoud van organisasies naas ander in die samelewing. 'n Sekulêre kerkbegrip lei noodwendig na sekulêre, horisontale, sosiale en selektiewe morele dinamika, en versteur die wese van kerkwees.

'n 'Kerk' as 'samelewingskring' verkry dan 'n vaste statiese vorm en ken geen spanning om aan transendente waardenorm te beantwoord om waarlik kerk van Christus te wees nie' So 'n 'kerk' stol in sy gearriveerdheid. (Spoelstra 1978)

Die NHKA het onwetend in hierdie denkpatroon verval en die dinamiek van kerkwees verloor in die proses van institusionele uitbreiding en bedieningsgestolheid. Lidmate het verval in 'n denkproses waar eienaarskap van kerkwees verlore geraak het en aan die predikant geabdikeer is.

Küng (1973) sien die dinamiek van kerkwees raak wanneer die nuwe volk van God die fundamentele struktuur van kerkwees daarstel. Küng fundeer sy kerkbegrip in die

6.Die begrip missio Dei word deur Dreyer (2016) saamgevat in die volgende uitdrukkings: "Dit gaan om God Drie-Enig wat self besig is om sy skepping te uitdrukkings: "Dit gaan om God Drie-Enig wat self besig is om sy skepping te transformeer en te verlos; Die kerk is ' $n$ geloofgemeenskap wat deelneem aan God
se handelinge deur te getuig van Jesus Christus; dit gaan om die verkondiging van die evangelie deur woord en sakrament; Dit gaan om die verbondsgemeenskap wat dissipels van Jesus Christus word; Dit gaan nie om die kerk se eie agenda of oorlewing nie. 
koninkryk van God en sluit daarmee aan by Calvyn wat 'die kerk tipeer as die ryk van Christus waar Hy deur sy Woord regeer (Institusie IV.2.4)' (Spoelstra 1978:100).

Besinning oor die kerk bring Küng by die feit dat die kerk altyd mense, gemeenskap van gelowiges, volk van God is (1 Pet 2: - 1 Pet 2:9, 10 9, 10). Die Here regeer sy volk deur sy Woord en Gees en roep hulle daarmee op om te antwoord met geloof, liefde en werke. Die werklikheid laat geen opening om die kerk as 'n abstraksie, 'n idee, 'n struktuur, 'n instituut, 'n regspersoon in eie reg te beskou nie. Die kerk is nie primêr instituut en/of organisasie nie. Die kerk is 'n dinamiese organisme waarin die instellings of institusionele dimensies aan die organisme die vorm van 'n ordelike liggaam gee (1 Kor 12). Inhoud en vorm kan juis kragtens die misterievolle wese van die kerk nooit geskei word nie (Küng 1973:5).

Van Wyk (2014:1) voeg hierby faktore wat nie so maklik kwantifiseerbaar is nie: swak bediening, dissonansie en ongeloof. Voeg hierby ook die kragte van sekularisasie, pluralisme, en die heerskappy van wetenskaplik tegniese denke (Van Wyk verwys in hierdie verband na Jenkins 2007).

In 'n modernistiese era het die wêreld 'n geslote sisteem geword wat kragtens 'n voorspelbare wetmatigheid gefunksioneer het. 'n Postmoderne bril vertel die verhaal van 'n oop sisteem organisasie wat as lewend getipeer word en in 'n gedurige proses van evolusionêre voortgang is. Dit geld veral die Kerk wat as 'n organisme getipeer word en dus die referensiële betekenis van lewe, groei en dinamiek verteenwoordig. Die gevaartekens vir die NHKA is geleë in die oënskynlike gestoldheid in geslote sisteemdenke wat die dinamiek van 'n oop sisteem perspektief vermy of ignoreer.

Die soekende gees wat in die NHKA vaardig geword het, is dalk juis die autopoetiese ${ }^{7} \mathrm{krag}$ wat tot vernuwing en 'n nuwe dinamika sal lei. As deel van hierdie nuwe energie, kan verwys word na die soeke na 'n effektiewe bedieningpraktyk vir gemeentes, gegewe ons sosio-ekonomiese en politieke omstandighede. Juis hierin lê hoop vir die toekoms.

Hoewel die Skrif na die kerk met betreklik statiese beelde verwys (tempel, gebou), is die dominerende profiel dié van 'n lewende organisme, 'n koinonia van mense (Spoelstra 1978:2, 3, 5). Die liggaam van Christus het 'n institusionele aspek, ruggraat of torso. Dit gee egter geen reg om 'n dualistiese onderskeid te tref tussen organisme en instituut, dinamies en staties, nie (Spoelstra 1978).

Daar bestaan 'n opvatting dat die kerk 'n objektiewe realiteit is wat op sigself ' $n$ menslose iets is. Dit impliseer 'n verskraling van die begrip 'kerk' en 'n verlies aan dinamiek en miskenning van 'n uitspraak soos byvoorbeeld: Julle is die liggaam van Christus en wat daarop volg. Spoelstra verduidelik:

7.Autopoesis as begrip word gebruik om te verwys na die selfskeppende of nuu skeppende potensiaal in organisasies.
Die Skrif dui met ekklesia en die Konfessie met 'vergadering van gelowiges' (NGB 27, 28; Heid Kat 21) tog onbetwisbaar duidelik aan dat die kerk mense is en nie 'n geobjektiveerde struktuur nie.

\section{Die wese van die kerk}

Perspektiewe op Wie en Wat die kerk is moet in die taal van mense onder woorde gebring word. Dreyer (soos aangehaal, p. $31 \mathrm{ev}$ ) beskryf ' $n$ hermeneutiese perspektief op die Kerk onder die begrippe: Die een God (Die kerk as volk van God); God die Vader (Die kerk as huisgesin van die Vader); God die Seun (Die kerk as liggaam van Christus); God die Heilige Gees (Die kerk as tempel van die Gees).

Alle bedieningfasette behoort geklee te word in verstaanbare taal en in metafore wat betekenisdraend is (sien in hierdie verband ook Dreyer 2011:156) (ook Nel 2016).

\section{Instandhouding van die missio dei}

'n Oorhoofse prinsipiële verskuiwing in die denke van die NHKA behoort plaas te vind. Dit impliseer'n groter fokus op die missio Dei en gevolglik die bedieningpraktyk en bedieningaktiwiteite wat in en deur die NHKA uitgevoer word. Hierdie verskuiwing vind plaas deur die praktiese toepassing van die verskuiwing na 'n bedieningfokus.

Die Kerk kom tereg in die gemeente wat in 'n bepaalde gemeenskap funksioneer. Navorsing ${ }^{8}$ dui daarop dat 'n gemeente wat 'n relatief beduidende impak in 'n gemeenskap maak (slegs 10\% van die gemeenskap raak), 'n geloofgemeenskap word wat deur die gemeenskap oorweeg sou kon word met die oog op toetrede. Dit gaan egter nie oor getalle nie, maar sonder getalle kwyn die gemeente in die gemeenskap en kom niks van die Kerk se roeping tereg nie. Dit behoort die eerste en mees kardinale verskuiwing te wees in die NHKA se denke oor kerkwees/gemeentewees. 'n Verskuiwing vanaf ' $n$ institusionele na ' $n$ missionale fokus is van kritieke belang. In hierdie verskuiwing lê die potensiaal vir kwalitatiewe groei opgesluit en sal die voortsetting van die Kerk vanself voortvloei.

Dreyer (2016:87 ev; verwys ook na [Pont 1995]) wat verwys na Calvyn se kerkbegrip as 'n kerkbegrip wat as gevolg van die sistemiese kontinuïteit tussen Heilige Skrif, Belydenis, Kerkorde, Amp, en Bedieningpraktyk, nie in 'n geslote sisteem gestol het nie. Hiermee saam sou dit ook tot heil wees as die NHKA terugkeer tot 'n Messiaanse en relasionele kerkbegrip (Dreyer 2016:92).

Nel (2015:202) pleit deurgaans vir 'n geïntegreerde en holistiese benadering tot gemeentelike bediening as 'n noodsaaklikheid, nie alleen om die gemeente op te bou nie, maar om die gemeente te reformeer en te oriënteer tot missionale bediening.

8.Navorsing deur Labuschagne dui daarop dat 'n gemeente wat slegs $1 \%$ van 'n . gemen bestaan. Wan kennis van die naam van die gemeente. Wanneer die gemeente $10 \%$ van 'n gemeenskap bereik, word die gemeente ' $n$ alternatief vir inskakeling (mededeling tydens 'n strategiese werksessie, Maart 2015) 


\section{Oorlading van die amp van predikant}

In hierdie verband kan verwys word na Die Kommissie vir ampsbediening en evangelisasie (Sinode Besluite 1978; 1994; 2002; 2004; 2007. ACTA van die Algemene Sinode van die NG Kerk):

- Sekularisasie van die ampsbegrip.

- Oorlading van sekere ampte.

- Gefikseerde ampsbegrip.

- Amp en bedieningpraktyk. 'n Enkele bedieningmodel of bedieningpraktyk ontken die diversiteit van die onmiddellike bestaankonteks van die gemeente.

- Roeping en beroep.

- Die dienswerk van gelowiges. Word verskraal tot dienslewering ter wille van die instandhouding en oorlewing.

Die NHKA se ampsopvatting moet getransformeer word en lidmate van nuuts af onderrig word of instaat gestel word om die begrip dissipelskap (Jones \& Van Eck 2010), of dan die priesterskap van die gelowiges, in praktyk te leef. Dit sou die predikantsamp reduseer tot die essensie daarvan.

\section{'n Kollektiewe geloofeenheid}

'n Gemeente kan nie op sigself en geïsoleerd Kerk wees nie. ${ }^{9}$ Eenheid is nie alleen gebaseer op strukturele verbande nie, maar is primêr gesetel in die belydenis van die Drie-Enige God soos geopenbaar in Jesus Christus en steeds teenwoordig deur die inwoning van die Heilige Gees. As kerk is die NHKA nie alleen EEN in die onderlinge geloofseenheid nie, maar ook in die kollektiewe akkoord wat voortspruit uit die gemeenskaplike bestaansgrond van elke gemeente, naamlik die God Drie-Enig. ${ }^{10}$

Die byeenkoms van die gemeente is ' $\mathrm{n}$ heilige moment. Die ontmoeting met God bly die kernmoment van die gemeentelike lewe. Wanneer die kerk (= gelowiges) die erediensruimte verlaat, betree die kerk die wêreld as draers van die evangelie.

As deel van die kerklike bediening word kennis geneem van mense se soeke na die sin van die lewe en spiritualiteit.

Die beeld van die NHKA in die samelewing kan alleen herstel word deur met integriteit deel te neem aan die openbare teologiese debat sonder om gearriveerd voor te kom. Ons is saam met die samelewing op soek na samelewingsorde wat tot voordeel van alle mense sal strek, omdat ons daartoe geroep is en dien dus nie net die belange van die NHKA nie.

Van der Merwe (2014) verwys na die tektoniese verskuiwings wat plaasvind in die 21ste eeu wat die Kerk

g.Die interafhanklikheid van die gemeente en die denominasie of kerkverband kan nie negeer word nie. Indien dit wel negeer of geïgnoreer word, verval die gemeente in 'n independentistiese bestaansmodus.

10. Hierdie stelling sluit nie die geloofsband met ander Christelike Kerke uit nie. Ons belydenis dat ons glo aan 'n Heilige, Algemene Christelike Kerk se draagwydte oorskrei die grense van die geloofsgemeenskap waarin ons tuis is. met 'n grootskaalse verleentheid laat. Hierdie verskuiwings raak elke denkbare dimensie van menslike bestaan en daar is geen aanduiding dat die tempo van verandering sal afneem nie.

\section{Tegnologie, kommunikasietegnologie en sosiale media}

Tegnologiese ontwikkeling het die manier waarop binne organisasies kommunikeer asook die bestuur daarvan, drasties verander. Kleiner vergaderings hoef nie meer fisiek gehou te word nie. Rolspelers wat geografies ver van mekaar verwyder is kan vergadering hou. Tegnologiese ontwikkeling skep nuwe kommunikasie patrone en transformeer die kommunikasiekultuur. Dit is egter nie net kommunikasiekultuur wat getransformeer word nie, maar ook breëre samelewingspatrone. Die sogenaamde Arabiese Lente waarvan die momentum te danke is aan virtuele netwerke en boodskappe wat wêreldwyd in regte tyd (real time) versprei is, is 'n goeie voorbeeld (sien Laker 2013).

\section{Gekoördineerde en verkorte besluitnemingsprosesse}

Besluitnemingsprosesse in die kerklike konteks word in 'n siklus van drie jaar voltrek, wat te lank is in 'n vinnig veranderende wêreld. Effektiewer besluitnemingsprosesse moet ontwikkel word wat fokus op die visie en missie van die Kerk ter wille van groter sinergie en samehorigheid met die oog op effektiewe uitvoering. Die fokus is dus 'n bedieningsgerigtheid.

\section{Weerstand teen verandering}

Weerstand teen verandering is ' $n$ wesenlike struikelblok in die voortdurende reformasie van die Kerk. Die Kerk mag egter nie blind wees vir die eise van voortdurende vernuwing binne die konteks van tyd en samelewingsomstandighede nie.

\section{Samevatting}

Hierdie artikel is bedoel as 'n breë aanduiding van die dimensies wat aanleiding gegee het tot die impasse waarin die NHKA haarself bevind. Die NHKA het in 'n institusionele doodloopstraat beland en kan alleen daaruit ontsnap deur die erkenning dat daar ' $n$ fokusverskuiwing moet plaasvind na 'n missionale ingesteldheid.

Die roeping van die NHKA is om Kerk te wees tot eer van die Drie-Enige God.

\section{Erkenning Mededingende belange}

Die outeur verklaar dat hy geen finansiële of persoonlike verbintenis het met enige party wat hom nadelig kon beïnvloed in die skryf van hierdie artikel nie. 


\section{Literatuurverwysings}

Ackoff, R.L., 1981, Creating the corporate future: Plan or be Planned for, Wiley, New York.

ACTA van die Algemene Sinode van die NG Kerk, (Sinode Besluite 1978, 1994, 2002 $2004,2007)$, Die Kommissie vir ampsbediening en evangelisasie.

Brisco, B., 2014, Living systems theory \& the church, viewed May 2014, from http:// blog.exponential.org/2014/05/living-systems-theory-the-church

Brown, M.Y., 2002, Patterns, flows, and interrelation ship, viewed from http:// mollyyoungbrown.com/essays-books-on-psychosynthesis-and-ecopsychology/ essays/patterns-flos-interrelationship/

Dreyer, W.A., 2011,"n Multidissiplinêre benadering tot Praktiese Ekklesiologie', HTS $67(2)$.

Dreyer, W.A., 2016, Praktiese Ekklesiologie - Kerkwees in die $21^{e}$ eeu, HTS Teologiese Studies Supplementum 10, AOSIS, Kaapstad.

Dreyer, Y., 2002, 'Perspectives on leadership in the world of the Bible: (De) institutionalisation as an ongoing process', Verbum et Ecclesia JRG 23(3), 625-641.

Flood, R. \& Carson, E.R., 1993, Dealing with complexity: An introduction to the theory and application of systems science, Plenum Publishing Corporation. https://doi. org/10.1007/978-1-4757-2235-2

Homrichhausen, C., 1999, 'Preaching as God's mission: Statement of understanding', in T. Kato (ed.), Preaching as God's mission, pp. 22-25, Ginza, Tokyo.

Jones, R. \& Van Eck, E., 2010, 'Die vorming van 'n eietydse ampsbegrip: Jesus se oproep tot dissipelskap', HTS Teologiese Studies/Theological Studies 66(1), Art. \#878, 1-10. https://doi.org/10.4102/hts.v66i1.878

Küng, H., 1973, The church, English translation, Search Press Ltd.

Labuschagne, F.J., 2015, Opmerking tydens ' $n$ werkwinkel van die Kommissie van die $A K V$, Filadelfia Gemeente.

Laker, L., 2013. The role of social media in the Arab Spring, The Arab Spring and Social Media Technology, viewed from https://www.academia.edu/4292069
Lorentsson, L., 2001,'The appropriateness of using the living systems theory by James Grier Miller as a diagnostic tool', M.Sc. dissertation.

Miller, J.G., 1978, Living systems theory, McGraw-Hill.

Nederduitsch Hervormde Kerk van Afrika, 2014, p. 436, Notule van die AKV, viewed from http://www.nhka.org/images/stories/70ste_AKV/12\%20-\%20(Ander\%20 sake.pdf

Nel, M., 2016, Identity driven churches, Biblecor.

Odendaal \& Gouws, Die HAT, Vyfde uitgawe, negende druk.

Shrader, R. 1998, 'Postmodernism', The Baptist Bulletin, viewed from http://www. readbag.com/bbc-journal-volume3-1-postmodernism-shrader

Spoelstra: Het ons kerkwees in strukture gestol? 1978, viewed from http://www.hts. org.za/index.php/HTS/article/viewFile/2131/3945

Steenkamp, P.L., 1997, 'Ontwikkelingsentrums in organisasieverband: 'n Instaatstellingsisteem', Ongepubliseerde Mphil verhandeling, Universiteit van Johannesburg.

Van der Merwe, J.C., 2013, 'Lense op spiritualiteit en kerkwees: Die pad vorentoe vir die Nederduitsch Hervormde Kerk van Afrika (NHKA)', HTS Teologiese Studies/ Theological Studies 69(1), Art. \#1988, 1-16. https://doi.org/10.4102/hts. v69i1.1988

Van der Merwe, J.C., 2014. "n Narratief vir kerk-wees vandag', HTS Teologiese Studies/ Theological Studies 70(1), Art. \#2699, 1-13. https://doi.org/10.4102/hts. v70i1.2699

Van Wyk, I.W.C., 2014, 'Klein en kleiner wordende gemeentes: Idees wat mag help', Tydskrif vir Hervormde Teologie 2(2), 22-39.

Van Zyl, M.A. \& Delport, C.S.L., 1993, 'Lewende sisteemteorie en gemeenskapsfunksionering', Die Maatskaplike werk-navorser-praktisyn 6(1), 2-7.

Verslag, 2015, 'Die volhoubaarheid van kerkwees in die toekoms', Voorgele aan die Kommissie van die Algemene Kerkvergadering, Februarie.

Wheatley, M.J., 1992, Leadership and the new science, Berret-Kohler, 2001 viewed from http://www.businessdictionary.com/definition/model.html\#ixzz2zbvCi5Dz 